\title{
Words Left Unspoken in the Lives of the Black
}

\author{
Vicky Chaparyan \\ Lebanese University
}

\begin{abstract}
Toni Morrison's fifth novel, Beloved, represents a postmodern traumatic story the characters of which deal with black history and the scars it has left on the African American community. As Rafael Perez-Torres claims, "the story of slavery invoked by Beloved is built on the absence of power, the absence of selfdetermination, the absence of homeland, the absence of a language" (Perez-Torres 1993:131). Throughout the story T. Morrison gives a voice to a ghost to speak up, but she takes away the voice of the ghost's mother who does not have the power to tell her story about her infanticide and so, has a troubled relationship with language. Later, Beloved's sister, Denver, who becomes dumb and deaf after learning the story about her mother's infanticide, gets back her senses when she goes to the community to ask for help to nurture her suffering mother. Although T. Morrison treats different themes, the following paper is an attempt to study the importance of language in Beloved, through comparing the Maternity symbolic order in Morrison to the Paternity symbolic order in Jacque Lacan's The Psychoses (1955-1956).
\end{abstract}

Key words: Beloved, slavery, Maternity symbolic order, Paternity symbolic order, J. Lacan, unspeakable thoughts, language, ghost, story of trauma.

\section{Introduction}

Root, Identity, and Community have always been the underlying themes of Toni Morrison's works. Through her novels, Toni Morrison shows several ways in which slavery, which was the most oppressive period in the black history, has affected the identity of African Americans (Chaningkhombee 2012).

Morrison's Beloved represents all the loved ones of the black Africans who died on the slave ship. Throughout the novel, she always returns to the theme of the sufferings of the black along with their marginalization and alienation in the societies of the white (Chaningkhombee 2012). Although African American literature traces its beginnings to the latter half of the $18^{\text {th }}$ century when the African American population was still enslaved (Gates; McKay 2004:3), Tony Morrison's 
Beloved written in the new era of the lives of the black people in the USA represents the sufferings caused by slavery that continue to live in the souls of the black population. The heavy presence of the ghost of Beloved is not but a symbol for all the victims of slavery. Reading the first few pages of Beloved, the reader can easily realize how Morrison reveals that the black race was treated "like an animal" during the time that the events of the story in her novel take place. For Morrison, each act of writing a novel is not but "an act of discovering deep within herself some relationship to a collective memory" (Rushdy 1992:149) For her, "writing is an instrument that can be traced back to an African heritage" (Rushdy 1992:149). She has written Beloved to reveal the story of her own race and their sufferings; a story which has long been forbidden to be told since "matters of race, silence and evasion have historically ruled literary discourse" (Morrison 1992:926). However, things have changed, "evasion has fostered another, substitute language in which the issues are encoded, foreclosing open debate" (Morrison 1992:926).

T. Morrison, a black writer, has encoded the evasion through which the stories of the black were forbidden to be told. Through the creation of a ghost, she gives life to the historical truths uncovering the inhumanity committed against her race. She takes away the voices of the mother and daughter, yet gives them back their voices to live and pass on the story that should never die.

\section{Morison's Maternity Symbolic Order Versus}

\section{Lacan's Paternity Symbolic Order in Beloved}

Beloved, the story of the dead incarnated, is as if a book of black history which is revealed through the memories of both people and ghosts which makes it a fantasy rather than a realistic novel. The core of Beloved's story of trauma consists of "the oscillation between a crisis of death and the correlative crisis of life: the between story of the unbearable nature of an event and the story of the unbearable nature of its survival" (Caruth 1996:3). Thus, Morrison is trying to tell a true story from black history using the device of a ghost, thus making it a fantasy because, although the slave narrative was by far the most common form of African American literature, fiction was also important (Gates; McKay 2004:2). The date of the story in the beginning of the novel goes back to 1873, which marks the aftermath of slavery and the Civil War. It encompasses levels of past from the slave ship called Middle Passage of "sixty million and more" slaves on the Pacific Ocean and their sufferings. It reveals the traumatic story of the black where Morrison depicts different means of suffering especially raping "as a process by 
which white men keep some black women and even some black men in a state of fear" (Barnett 1997:425). The novel rotates around the true story of Margaret Garner who is the victim of racist ideology of the whites during slavery and decides to kill her children, so that no white man with "mossy teeth" will ever hold her child down and suck the milk out of her breasts (Morrison 2005:70).

The whole story is interwoven around the main character, Sethe, who is just thirteen years old when she arrives at Sweet Home as a slave girl. Much of the information that weaves the story together does not follow a timeline. It moves from past to present back and forth. It is written in fragments of memories and is told in third person narration through the memories of Sethe, Denver, Paul D, and Baby Suggs. The language used is typical of the language of the black Americans and it is lost over and over again throughout the novel with Sethe, the protagonist of the novel, as well as her daughter Denver. Both characters lose their speech abilities because of the murder committed by Sethe.

It is through the device of the ghost story that Morrison "gives a voice to an infant killed by her own mother who is desperate to save her child from slavery" (Wyatt 1993:474). The dead baby comes back in the body of a nineteen year old girl and tortures the mother with a sadistic desire to make her suffer. Sethe and Beloved are inseparable because, as Boyd claims, "mothers and daughters identify with each other" (Boyd 2008:292). Thus, the ghost of Beloved has come back to identify herself with her mother. She wants to take revenge and Sethe becomes her slave serving her willingly. However, Beloved is not only Sethe's daughter, but a symbol of all the victims of slavery, that presents a vision about slaves, whether men or women, awakening past memories (Wyatt 1993:475). Moreover, although Morrison reveals Beloved as a female, yet she does not represent the female gender. She, who is both the rapist and the victimizer, represents black people (male and female) who suffered all types of sufferings, because the white did not care whether the slaves were male or female to abuse them. The narrator refers to two "mossy teethed" boys sucking Sethe's milk from her breasts (Morrison 2005:228) and Paul D working on a chain gang where prisoners were forced to fellate white guards every morning, (Morrison 2005:107). As a result of the suffering, all the houses of the black people were haunted by ghosts. Sethe's mother-in-law, Baby Suggs says, "Not a hause in the country ain't packed to its rafters with some dead Negro's grief. We lucky this ghost is a baby" (Morison 2005:6). All the characters in the book deal with black history and the wound it has caused to them. All are haunted by traumas of slavery and racism, 
with the scar of the past returning to them over and over again. Sethe's horrific explanation of the abuse of the white is "Whites do not just work, kill, or maim you, but dirty you. They dirty you so bad that you cannot like yourself anymore" (Morrison 2005:251). This explains why Sethe prefers killing her daughter with her own hands instead of letting her suffer the way she herself did. Jean Wyatt says, "When Sethe tries to attempt to kill herself and her children to prevent their re-enslavement, she finds her speech blocked" (Wyatt 1993:476). Moreover, Wyatt adds that "Sethe's maternal subjectivity is so embedded in her children that it both allows her to take the life of one of them and precludes putting the act into words" (Wyatt 1993:476). Sethe cannot tell the story of her infanticide in words. She has trouble with language. Although she finds the strength to kill her child, yet she cannot tell the story of murdering to the other women in her community.

Throughout the novel, T. Morrison shows that all the characters are haunted with the traumas of the past, that is why they all have to deal with their history, with their wounds, and their painful past to be able to be healed. Sethe cannot find language to tell about her infanticide, and Denver becomes deaf and dumb after learning about the murder her mother has committed. However, towards the end of the novel, T. Morisson shows that Sethe is not able to search her identity without the help of her community because while Sethe operates within her own sense of maternity, it is Denver who, at the end, finds a replacement for Lacan's Paternal symbolic order, as well as "a social order that merges oral and verbal pleasures, nurtures her with words and teaches her that caring is what language was made for" (Wyatt 1993:475). Thus, Sethe's daughter Denver goes out to her community to ask for help, to nurture her mother who was suffering and to gain back the senses that she has lost.

For Wyatt “Morrison's story holds an opposition between a maternal order of nurturing and a paternal order of abstract signification" (Wyatt 1993:482). Thus, accordingly, the state of Sethe presenting the maternal values contradicts Lacan's theory of paternity which in turn "enables Morrisson to contrast a new narrative form that features childbirth as high adventure." Sethe "occupies a contradictory position in discourse" (Wyatt 1993:475). She embodies the figures of both the mother and the father for Beloved. Morrison "elaborates the heroic slave mother in such a way that she replaces the figure of the heroic male" (Wyatt 1993:475), because the central heroic achievement of Sethe's journey is part of her suffering while giving birth on a sinking boat. Although she is eager to give up and die, she, however, keeps on fighting to survive for the sake of the baby in her womb. Thus, 
Lacan's theory of Paternity turns to be called the symbol of Maternity with Morrison's Beloved in general and with the black race in particular. M. Sharpe, comparing the concept of a child's entry into language in Morison's story (where the daughter suffers of a trauma) to Lacan's concept, deduces that for Lacan, "it is only when the child accedes to castration and the Law of the father, that he becomes fully competent as a language-speaker within his given social collective. By contrast, individuals suffering from psychosis, are prone to characteristic linguistic dysfunctions and inabilities" (Sharpe 2004: Web). Thus, Lacan sums up the psychological requirements for belonging to a patriarchal symbolic order. However, according to Jean Wyatt, Morrison's deviations from dominant language practices can be called "maternal symbolic order incorporating not only maternal and material values but also a system that, like Lacan's symbolic order, "locates subjects in relation to other subjects" (Wyatt 1993:475).

The narrative of the Beloved focuses on either the maternal body or the haunted house, and there are different metaphors that control the symbolic dimension of things to adhere to their literal meaning. Sethe has a troubled relation with respect to language and special metaphors reflect materialization of things. An example is a figure of speech where weight which also means "responsibility" turns out to describe only the physical weight of Sethe's breasts. Another example is the word moved in "She moved him." This use of the word does not indicate that Beloved stirred Paul D's emotions but that she physically moved him from one location to another (Wyatt 1993:475).

Sethe's physical connection with her baby resembles the infant's initial radical dependency on the mother's body. However, according to Wyatt, in its drive toward unity, the mother - daughter dialogue wipes out all the positions of separation necessary for language, and it is in this sense "unspeakable" (Wyatt 1993:479). The conversation of Sethe and her two daughters, Denver and Beloved, is "unspeakable thoughts" because the sufferings of the black are so harsh and inhumane that they exceed the level of ordinary discourse. Moreover, Beloved herself "ends up outside social discourse. Her position in the epilogue is symmetrical with that of the Sixty Million and more... the souls that never made it into any text" (Wyatt 1993:479), for no one wrote about those sufferings. They were forgotten and passed on. Morrison writes, "Everybody knew what she was called, but nobody anywhere knew her name. Disremembered and unaccounted for, she cannot be lost because no one is looking for her, and even if they were, how can they call her if they don't know her name? Although she has claim, she is not 
claimed" (Morrison 2005:274). He adds, "This is not a story to pass on" the sufferings of the black were so great that they were not supposed to pass on from one generation to the other. They are supposed to be forgotten "like a bad dream" (Morrison 2005:324).

At the end of T. Morrisson's story, it is Denver, Sethe's surviving daughter who finds a replacement for Lacan's paternal symbolic order - a social order that merges oral and verbal pleasures, nurtures her with words, and teaches her that caring is "what language was made for" (Wyatt 1993:475). As she comes to know about her mother's infanticide, Denver cannot find language to speak with. She becomes deaf and dumb for two years, "cut off by an answer that she could not hear, cut on by the sound of her dead sister trying to climb the stairs" (Morrison 2005: 122). However, with the urge of getting food for her starving mother she goes to the community where she learns that she is not alone, and that she's a child of the community. She learns how important it is "to belong to the community of other free Negroes, to love and be loved by them, feed and be fed" (Morrison 2005:177). Moreover, "It is the speech act itself, the voice of the grandmother, putting the past where it belonged, into oral history that frees Denver to enter the present" (Wyatt 1993:483). Otherwise stated, it is the idea of belonging to the community of other Negros that helps Denver "enter the nurturing reciprocity" (Wyatt 1993:483).

Denver lives in the free state of Ohio and belongs to "the first unenslaved generation", thus representing possibilities for the future (Carden 2007:2). At the end of the story, the author makes Denver get back his senses through the help of the community and Sethe establishes a new bond with Paul D and coming together with him makes a happy family, thus carrying the potential for repair and rejuvenation, that produces normative families, communities, cultures (Carden 2007:4). Thus, Denver and Sethe are both cured and get back their speech which they had lost because of infanticide, due to finding social and romantic links with the society they live in.

According to Wyatt, the hope at the end of the novel is that Sethe will invent a language that transfers the desperation of the slave mother who committed infanticide. Moreover, as a victim of slavery and as a preverbal infant who has not made her way into the symbolic order, Beloved remains outside language and therefore outside narrative memory... Beloved's story too, terrible to find a resolution in the logic of narrative, cannot be passed on from teller to teller, but it also cannot die (Wyatt 1993:484). 
Thus, accordingly, if black history survives, then black people have to remember their history and pass it on from one generation to another, for a black child has to know that in the past his ancestors were used to be beaten, whether they were right or wrong. "The schoolteacher beat him anyway to show him that definitions belonged to the definers - not to the defined" (Morrison 2005:225). They have to know that they were sold and lost all around the Pacific and the Americas, and that "the sold one never returned, the lost one was never found" (Morrison 2005:147). However, mourning on the past would not help; but telling the story will do. Telling the story of the injustice committed against the black Americans will let the memory of the dead live forever. All the characters in the novel have to remember the past in order to forget it later.

Thus, managing to turn infanticide and the cry of slavery around, the society succeeds in building a further case for abolishing slavery. The appearance of Beloved in the story symbolizes the past which has tortured the black people, and the scar left by her is an appeal and exhortation for the coming generations never to forget the past and the sufferings of the black people, for it is true that "the ancestor lives as long as there are those who remember" (Rushdy 1992:149).

\section{Conclusion}

Through the story of the ghost, T. Morrison presents the power of language which is blocked in the black mother who committed infanticide with the hope of preventing the enslavement of her daughter. Beloved represents all the black Africans who suffered and died on their way in the Pacific to America to find food and shelter there. She reveals how they were abused by the white race and how they were forbidden from any feeling of body pleasures like love, sex, and baby feeding.

Moreover, throughout her novel, T. Morrison proves that the ghost of slavery haunts the black people of African origin. The effect of the ghost is so powerful that it blocks the speeches of both Beloved and her mother. But the community helps her for it is only due to the community that Denver gets back her speech and helps her mother who finds the possibility of making the unspeakable spoken through establishing a romantic bond with Paul D and a social one with her community Thus, Morrison reveals that it is only through talking about the wound of slavery and showing care and love to one another that the blocked speech can be unblocked again, and the wound of slavery left over the generations of the black Africans can be healed. 


\section{Notes:}

1. J. Lacan uses Freud's concept of the mythical father as a strategic move in his opposition to the relationship of the individual and his/her mother as a dual pair. He emphasizes the importance of the third party in the Oedipus complex, i.e., in his terms, the place that the mother reserves for the Name-of-the Father in the promulgation of the law. He considers this a vital element in helping each new member of the human race to move from an exclusive, primary relation to the mother to a wider engagement with the outside, cultural world - the symbolic order. He believes that the symbolic function of a Father has been identified with the figure of the law since the dawn of history (Lacan 1955-1956).

\section{References:}

1. Barnett, P.E. (1997) Figurations of Rape and the Supernatural in Beloved. // PMLA, Vol. 112, N. 3. Modern Language Association. Available at: $<\mathrm{http}$ ://www.jstor.org/stable/462950> JSTOR database [Accessed June 2016].

2. Boyd, C. (2008) Contemporary Fiction: An Anthology of Female Writers. New Delhi, India: Saroup and Sons.

3. Chaningkhombee, S. (2012) Reconstruction of Black Identity and Community in Toni Morrison's Beloved and the Bluest Eye. Available at: <www.academia.edu $>$ [Accessed May 2016].

4. Carden, P. (2007) Models of Memory and Romance: The Dual Endings of Toni Morrison's Beloved. Available at:

$<$ www.oocities.org/tarbaby2007/beloved11.htm> [Accessed June 2016].

5. Caruth, C. (1996) Unclaimed Experience: Trauma, Narrative, and History. Baltimore: Johns Hopkins UP.

6. Gates, H.L.Jr. and McKay, N.Y. (2004) The Norton Anthology of AfricanAmerican Literature. New York: W.W. Norton \& Company.

7. Lacan, J. (1955-1956) Psychoses (Seminars). Available at: <wikiprdia.org/wiki/ The_Name_of_the_Father $>$ [Accessed June 2016].

8. Morrison, T. (2005) Beloved. London: Vintage.

9. Morrison, T. (1992) Ethnic Studies, Post Coloniality, and International Studies; Playing in the Dark: Whiteness and the Literary Imagination. Available at: $<$ http://www.jstor.org $>$ JSTOR database [Accessed May 2016]. 
10. Perez-Torres, R. (1993) Knitting and Knotting the Narrative Thread Beloved as Post Modern Novel. // MFS: Modern Fiction Studies 39, N. 3-4. Retrieved on May 29, 2016 from JSTOR database.

11. Rushdy, A.H.A. (1992) Daughters Signifying History: The Example of Tony Morrison's Beloved. // American Literature 64/3. Available at: $<$ http://www.jstor.org/stable/2927752> JSTOR database [Accessed May 2016].

12. Sharpe, M. (2004) Internet Encyclopedia of Philosophy. University of Melbourne, Australia. Available at: $<\mathrm{http} / / / \mathrm{www}$.iep.utm.edu/lacweb> JSTOR database [Accessed May 2016].

13. Wyatte, J. (1993) The Maternal Symbolic in Tony Morrison's Beloved. // PMLA, Vol. 108, N. 3. Modern Language Association. Available at: $<$ http://www.jstor.org $>$ JSTOR database [Accessed May 2016].

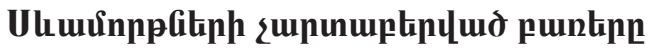

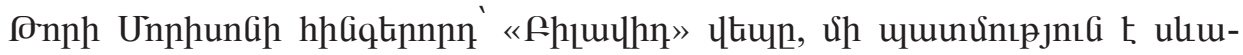

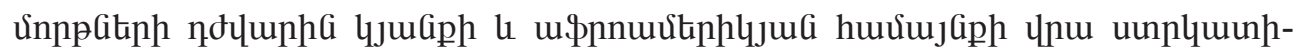

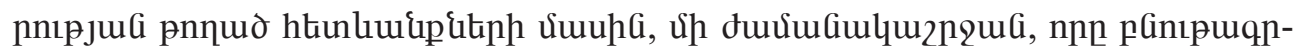

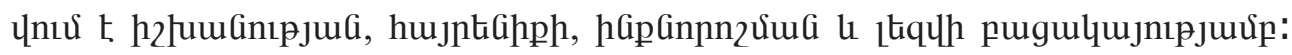

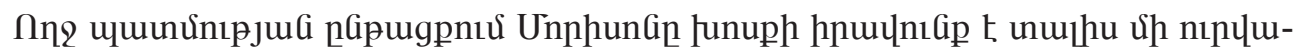

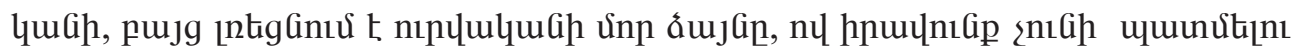

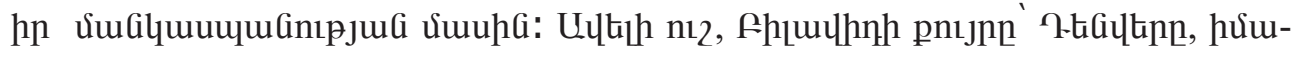

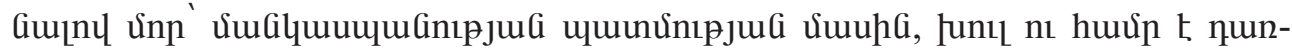

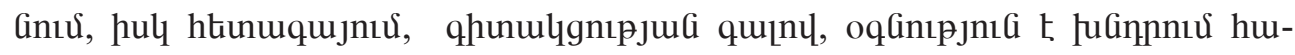

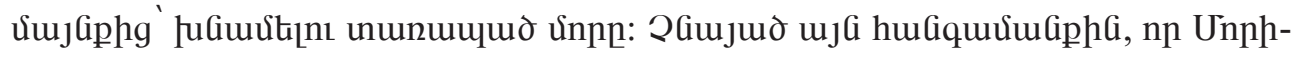

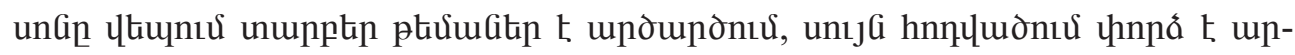

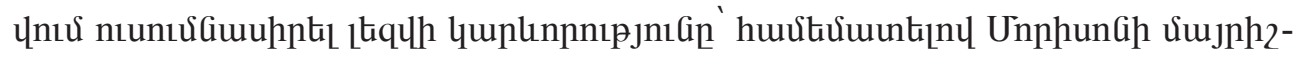

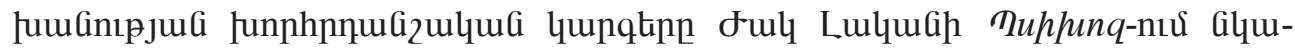

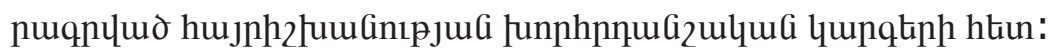

